African Journal of Educational Studies in Mathematics and Sciences Vol. 15. 2019

\title{
An Assessment of the Impact of Improvised versus Conventional Laboratory Equipment on Students' Performance in Thermal Expansion
}

\author{
K. Ndihokubwayo ${ }^{1}$, J. Uwamahoro ${ }^{2}$, and I. Ndayambaje ${ }^{3}$
}

\begin{abstract}
Science education in Rwandan schools still faces a number of challenges including the lack or shortage of equipment available for science experiments. This paper describes research conducted to assess the impact of using improvised versus conventional laboratory equipment in experiments. Eighty-five lower secondary school students were assessed using a semiexperimental post-test design on thermal expansion of bodies. Data analysis using a t-test produced a t-Stat of 2.74 over a t-Critical of 1.98 indicating a statistical significance between the two experimental groups in favor of the group using improvised equipment. As a result, it is recommended that improvised equipment be used in those instances in which there is a lack or shortage of conventional equipment since students' achievement was similar regardless of the type of equipment used.
\end{abstract}

Keywords: $\quad$ improvised experiments; conventional equipment; thermal expansion

\section{Introduction}

According to Piaget (1970) in Onwioduokit (2013), children learn best through doing and actively exploring their environment. By implication, therefore, science should be taught in such a way that students themselves carry out useful activities. Thermal expansion of bodies is among demonstrative phenomenon in heat and thermodynamics that Physics learners should enjoy. Most science teachers perceive that laboratory activities are essential in teaching science as they stimulate students' interest and develop their scientific skills (Dillon, 2008), and hands-on activities are the most successful strategy for effective science teaching and learning (Sandifer \& Haines, 2009). Experiments offer students opportunities to think about scientific concepts and to discuss and solve problems (Amimbola, 2006; Woodley, 2009). Experimental learning may provide a strong base for students to develop long-term memory as they have the opportunity to learn by doing (Tobin, 2008). In addition, a deep understanding of science concepts comes with practical instruction (Olufunke, 2012) because practical activities engage students through data collection, interpretation and making inferences (Mortimer \& Scott, 2003). Consequently, the teaching of science which does not incorporate practical work is out of step with the ideals of science teaching (Omolo, 2009) because students may not be able to connect theoretical scientific concepts with the real world they live in (Suleiman, 2013).

\footnotetext{
${ }^{1}$ Kizito Ndihokubwayo, PhD student in Science Education at the African Centre of Excellence for Innovative Teaching and Learning Mathematics and Science (ACEITLMS), University of Rwanda-College of Education (URCE) Kigali, Rwanda. Email:ndihokubwayokizito@gmail.com

${ }^{2} J e a n$ Uwamahoro, Deputy Director at ACEITLMS and Senior Lecturer at University of Rwanda-College of Education (UR-CE), Kigali, Rwanda. Email: mahorojpacis@gmail.com

${ }^{3}$ Irénée Ndayambaje, Director General (DG) of Rwanda Education Board (REB), Kigali, Rwanda. Email: irenee.ndayambaje@gmail.com
}

Open Access article distributed under the terms of the Creative Commons Attributions License [CC BY-NC-ND 4.0] http://creativecommons.org/licenses/by-nc-nd/4.0. DOI: https://dx.doi.org/10.4314/ajesms.v15i1.11 
An assessment of the impact of improvised versus conventional laboratory equipment on students' performance in thermal expansion

K. Ndihokubwayo, J. Uwamahoro, and I. Ndayambaje

Through science experiments, students will be able to reflect on natural events and carry out activities that will enhance their cognitive skills (Eren et al., 2015). Experimental work is an active learning method requiring students to observe or manipulate real objects and materials, all of which have a distinctive and central role in the development of students' understanding of scientific concepts, improving cognitive skills as well as developing positive attitudes to the discipline (Tarhan \& Sesen, 2010). This is why it is recommended that science teaching and learning should be focused on the use of scientific activities to investigate real-life phenomena (Hofstein \& Mamlok-Naaman, 2007; Tobin, 2008). However, as Angus and Keith (1992) ask; "Do we obtain a good quality education when teachers make a few demonstrations using expensive or sophisticated equipment?". The scarcity and cost of imported materials for teaching science have remained a major challenge to teaching sciences in developing/ non-Western countries (Nkechi \& DomNwachukwu, 2006). Hence, improvisation in science education is of paramount importance in developing countries. According to Nkechi and DomNwachukwu (2006), such improvisation involves the adaptation or modification of original materials and equipment so that they can perform new functions in the laboratory.

Physics is a key subject in the secondary school curriculum because it enables learners to apply the principles, acquired knowledge and skills to construct appropriate scientific devices from available resources (Wambugu, Changeiywo \& Ndiritu, 2013; Daniela, Popescu, Ioan, \& Andrei, 2015). However, researchers have found that students find it difficult to grasp abstract concepts such as heat, light, electricity, magnetism, etc. (Welzel, 1998). Teaching thermal expansion as relationship of temperature with the tendency of shape, area, and cubic change of matter has faced challenges in enhancing students' interest during experimentation due to the lack of effective and easy materials. Therefore, the aim of this study was to compare the performance of students who were taught thermal expansion unit using improvised (teacher-made) or conventional (standardized) equipment. The findings of this study are expected to benefit science teachers in all Rwandan secondary schools in assessing the potential of improvising local materials to let students grasp and enhance their understanding of concepts related to thermal expansion specifically and heat and thermodynamics in general.

\section{Methodology}

The research aimed to measure the effectiveness of improvised versus conventional laboratory equipment on student learning and was conducted with the participation of 85 Grade 7 students from two classes (made up of 44 students and 41 students respectively) randomly selected from a secondary school in the eastern province of Rwanda in the 2015 academic year. This study was of a semi-experimental post-test comparative design conducted within the scope of a thermal expansion topic, with experiments carried out using improvised equipment in the case of the first group and conventional equipment with the second group. In the implementation stage of the research, each group conducted 3 experiments over a 3 lesson period in one week. A semi-openended experiment method (Aydoğdu et al., 2013), where the open parts of the experiment are expected to be completed by the students was used. In addition to experiment worksheets given to both groups, students in one group were given improvised materials such as a wooden plate, 2 nails and a coin, water, aluminum can and alcohol, straw, pet bottles and balloons, while the conventional equipment group was given traditional laboratory materials such as a bimetal strip, a metal ring with a ball, a glass beaker, a jar of water and a Bunsen burner. After performing these 
experiments related to thermal expansion (linear, area, and volume), an open-ended test was completed by both groups.

\section{Results and Discussion}

In terms of data analysis, the t-test was used for independent samples in test scores obtained from the improvised and conventional equipment groups. The test was marked out of 5 as the total score from all questions asked ( 1 score for each test area). Table 1 shows all scoring procedures and descriptive findings.

Table 1 Scoring area and Descriptive statistics

\begin{tabular}{llcccccc}
\hline & \multicolumn{3}{c}{ Improvised Lab } & \multicolumn{3}{c}{ Conventional Lab } \\
\cline { 3 - 8 } & Area of test questions & $\begin{array}{c}\text { Frequ- } \\
\text { ency }\end{array}$ & $\begin{array}{c}\text { Mean } \\
\text { score }\end{array}$ & SD & $\begin{array}{c}\text { Frequ } \\
\text { ency }\end{array}$ & $\begin{array}{c}\text { Mean } \\
\text { score }\end{array}$ & SD \\
\hline 1 & Properties of "Cooling wood" & 11 & 0.25 & 0.43 & 15 & 0.37 & 0.48 \\
2 & Properties of "heated Aluminium can" & 34 & 0.77 & 0.42 & 25 & 0.61 & 0.49 \\
3 & Experiment on "Linear thermal expansion" & 31 & 0.7 & 0.46 & 21 & 0.51 & 0.5 \\
4 & Experiment on "Areal thermal expansion" & 18 & 0.41 & 0.49 & 18 & 0.44 & 0.5 \\
5 & Experiment on "Volume thermal expansion" & 27 & 0.61 & 0.49 & 6 & 0.15 & 0.35 \\
& Total & & 2.75 & 1.19 & & 2.07 & 1.05 \\
\hline
\end{tabular}

Figure 1 shows the means of students' scores with the improvised equipment group generating a mean of 2.75 while the conventional equipment group had a mean of 2.07.

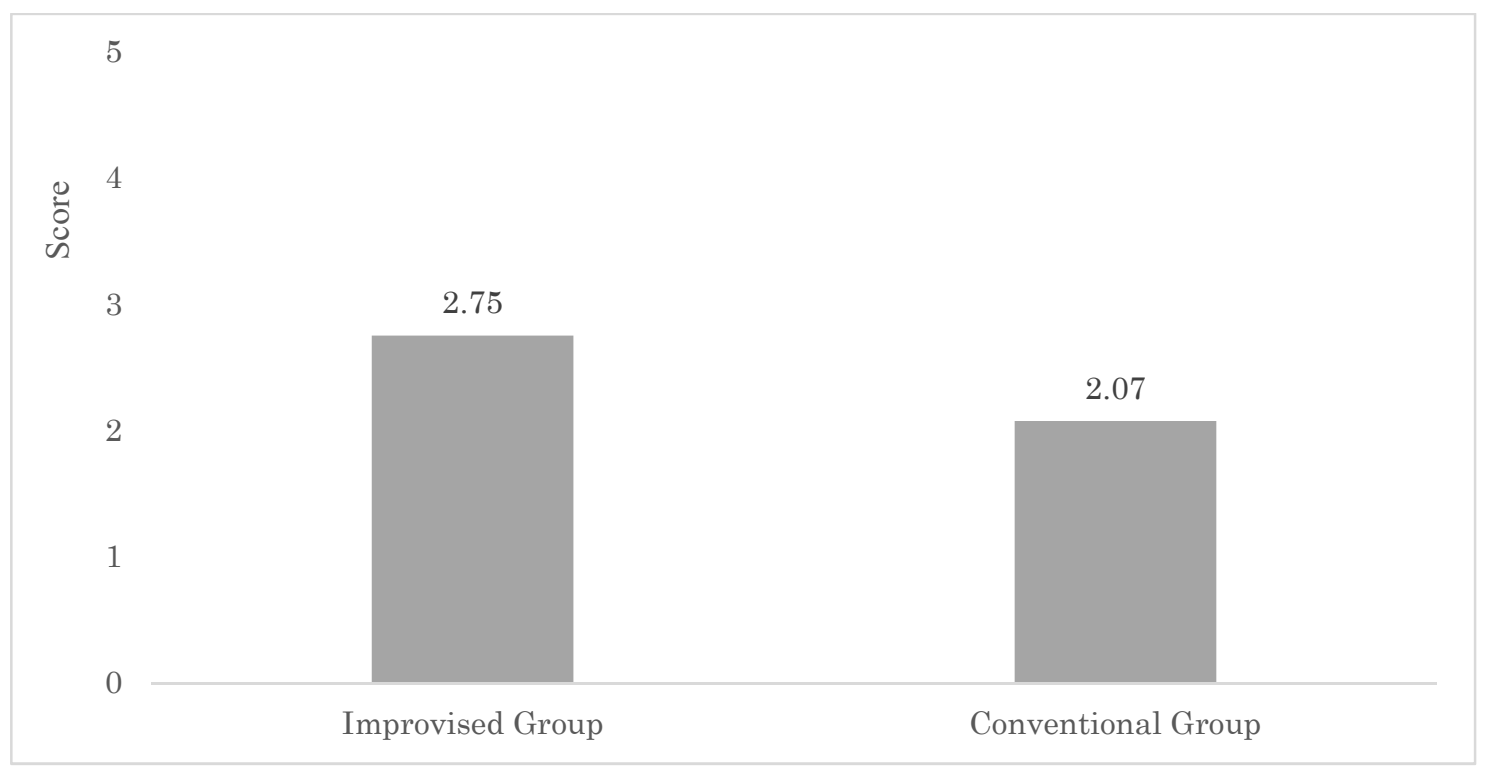

Figure $1 \quad$ Mean score of all groups

Thus, the t-test for independent samples of test scores from the improvised and conventional experiments produced a t-statistic of 2.74 when a t-critical one tail of 1.66 at 83 degrees of freedom 
An assessment of the impact of improvised versus conventional laboratory equipment on students' performance in thermal expansion

K. Ndihokubwayo, J. Uwamahoro, and I. Ndayambaje

was considered (See Table 2). Therefore, there was a statistical significance between these groups in favor of the improvised equipment group.

Table 2 T-test of two-sample assuming equal variances of improvised and conventional equipment groups

\begin{tabular}{lrr}
\hline & Improvised & Conventional \\
\hline Mean & 2.75 & 2.07 \\
Variance & 1.447674419 & 1.119512195 \\
Observations & 44 & 41 \\
Pooled Variance & 1.289523949 & \\
Hypothesized Mean Difference & 0 & \\
$\mathrm{df}$ & 83 & \\
$\mathrm{t}$ Stat & 2.745827361 & \\
$\mathrm{P}(\mathrm{T}<=\mathrm{t})$ one-tail & 0.00369937 & \\
$\mathrm{t}$ Critical one-tail & 1.663420175 & \\
$\mathrm{P}(\mathrm{T}<=\mathrm{t})$ two-tail & 0.00739874 & \\
$\mathrm{t}$ Critical two-tail & 1.98895978 & \\
\hline
\end{tabular}

There seems little doubt that the materials of greatest value are those to be found in the immediate environment because these are within everyone's experience and they are less expensive than traditional science laboratory equipment (Angus \& Keith, 1992). The results from the present study confirm those of by Ekpo and Ushie (2010) who found improvisation of materials to be generally better-suited to the climatic conditions of the local environment since learners will interact with the materials around them every day, thereby promoting local sourcing of experimental materials and encouraging the creativity of teachers and learners. Like in the present study, the study conducted by Owolabi and Oginni (2012) also showed that there was a significant difference in the performance of students who used improvised and non-improvised resources. The study of Udosen and Ekukinam (2013) using a t-test statistical analysis also revealed that pupils benefited equally from the standardized science and improvised equipment. In addition, they highlighted the efficiency of low-cost apparatus in regards to time, separation, convenience, and durability which was about $98 \%$ compared to factory manufactured ones (Sileshi, 2012). In the present study, the improvised materials like plastic bottle, straw and balloon can demonstrate volume thermal expansion than conventional materials like a bimetal strip could do. For instance, 27 out of 44 students in improvised lab alongside 6 out of 41 students in conventional lab performed test question related to volume thermal expansion (see Table 1).

\section{Conclusion and Policy Implication}

A statistical significance between the use of improvised and conventional equipment occurred in favor of the improvised group. It is, however, important to note that complicated or precision instruments may not be improvised as easily due to their complexity and specificity (Udosen \& Ekukinam, 2013). As a recommendation, because of the generally greater accuracy of conventional equipment, where possible, improvised experiments should also be carried out alongside 
conventional experiments using ready-made equipment. Since the improvised materials showed potential in learning achievement as well as being low cost, educational institutions should find ways of creating and sharing readily available resources that can be used to teach specific subjects such as Physics and Science, in general. In addition, pre- and in-service teachers should be actively encouraged and trained to make use of materials available in their immediate environment.

\section{References}

Abimbola, I. O. (2006). A critical appraisal of the role of laboratory practical work in science teaching in Nigeria. http://www.unilorin.edu.ng/

Angus, R. Ross, \& Keith, M. Lewin. (1992). Science kits in developing countries: an appraisal of potential. International Journal of Educational Development.

Aydoğdu, Bülent, Buldur, Serkan, \& Kartal, Sebahattin. (2013). The Effect of Open-ended Science Experiments based on Scenarios on the Science Process Skills of the Pre-Service Teachers. Procedia - Social and Behavioral Sciences, 93, 1162-1168. doi: 10.1016/j.sbspro.2013.10.008

Daniela, Cziprok Claudia, Popescu, F. F., Ioan, Pop Alexandru, \& Andrei, Variu. (2015). Conceptual Maps and Integrated Experiments for Teaching/Learning Physics of Photonic Devices. Procedia - Social and Behavioral Sciences, 191, 512-518. doi: 10.1016/j.sbspro.2015.04.284

Dillon, J. (2008). A Review of the research on practical work in school science. King's College, London, 19.

Ekpo, O. E., Ushie, B. C. et al (2010). Improvisation of instructional materials for primary schools. In UBE teachers' professional development workshop manual on improvisation of instructional materials for primary schools. Cross River State 4th -16 th January.

Eren, C. Dilek, Bayrak, B. Karadeniz, \& Benzer, E. (2015). The Examination of Primary School Students' Attitudes toward Science Course and Experiments in Terms of Some Variables. Procedia - Social and Behavioral Sciences, 174, 1006-1014. doi: 10.1016/j.sbspro.2015.01.1245

Hofstein, A. \& Mamlok-Naaman, R. (2007). The laboratory in science education: the state of the art. Chemistry Education Research and Practice, 8 (2), 105-107.

Mortimer, E. F., \& Scott, P. (2003). Meaning making in secondary science classrooms. Buckingham: Open University Press. Retrieved from http://site.ebrary.com/id/10172349

Nkechi S., DomNwachukwu, \& DomNwachukwu, Chinaka S. (2006). The Effectiveness of Substituting Locally Available Materials in Teaching Chemistry in Nigeria: A Case for Science Education in Developing Countries School Science and Mathematics 106(7), 296305.

Olufunke, B. T. (2012). Effect of availability and utilization of physics laboratory equipment on students' academic achievement in senior secondary school physics. World Journal of Education, 2(5). doi:10.5430/wje.v2n5p1

Omolo, A. O. (2009). Science teachers' perception of the role of practical work and their influence on the teaching of secondary school science: A Case Study. Aga Khan University.

Onwioduokit, F. A. (2013). The Ordeal of Science Teaching in the contemporary Society: A need for Paradigm Shift for the New Generation. 36th Inaugural Lecture Series of the University of Uyo. 
An assessment of the impact of improvised versus conventional laboratory equipment on students' performance in thermal expansion

K. Ndihokubwayo, J. Uwamahoro, and I. Ndayambaje

Owolabi, Olabode Thomas, \& Oginni, Omoniyi Israel. (2012). Improvisation of science equipment in Nigerian schools. Universal Journal of Education and General Studies 1(3), pp. 044-048.

Piaget, J. (1970). Science of Education and the Psychology of the Child. New York: Orion Press.

Sandifer, C., \& Haines, S. (2009). Elementary teacher perceptions of hands-on science teaching in an urban school system: The greater educational context and associated outcomes. Research in higher education Journal, 2(3), 117.

Sileshi, Yitbarek. (2012). Low-Cost Apparatus from Locally Available Materials for TeachingLearning Science. African Journal of Chemical Education, 2(1, Special Issue).

Suleiman, M.M. (2013). Exploring Science Teachers' Experiences Of Teaching Science with Limited Laboratory Resources: A Case Study of Community Secondary School In Lindi, Tanzania. (Master's Dissertation), Aga Khan University Tanzania Institute for Higher Education Institute for Educational Development, Eastern Africa, Tanzania. Retrieved from http://www.grin.com/en/e-book/282010/teachers-experiences-of-teaching-sciencewith-limited-laboratory-resources.

Tarhan, Leman, \& Sesen, Burcin Acar. (2010). Investigation the effectiveness of laboratory works related to "acids and bases" on learning achievements and attitudes toward laboratory. Procedia - Social and Behavioral Sciences, 2(2), 2631-2636. doi: 10.1016/j.sbspro.2010.03.385

Tobin, K. G. (2008). Teaching and learning science: A handbook. Lanham, Md: Rowman\& Littlefield Education

Udosen, Idongesit N., \& Ekukinam, Thelma U. (2013). Improvisation of Technological Instructional Media and Students' Performance in Primary Science in Nigerian Schools. World Conference on Science and Technology Education

Wambugu, P.W., Changeiywo, J.M., \& Ndiritu, F.G. (2013). Effects of Experiential Cooperative Concept Mapping Instructional Approach on Secondary School Students'achievement in Physics in Nyeri County, Kenya, Asian Journal of Social Sciences \& Humanities, 2(3), 279-296

Welzel, M. (1998). The emergence of complex cognition during a unit on static electricity. International Journal of Science Education, Vol. 20, No. 9, Sf. 1107-1118.

Woodley, E. (2009). Practical work in school science why is it important? School Science Review, 91(335), 4951.

\section{Acknowledgment}

The authors highly appreciated the effort made by Dr. Massango Herieta from Hiroshima University for guidance in preparing experimental materials related to Thermal expansion, Prof Tsutaoka Takanori from Hiroshima University for mentoring in developing the basic ability for science and technology, and Mrs. Mukamana Valentine for research assistance. 